\title{
I. Dünya Savaşı Yıllarında Balkan Muhacirlerinden Alınan Hisse-i Teavün Vergisi*
}

\section{Hisse-i Teavün Tax Collected From Balkan Migrants During World War I}

\author{
Nuray ÖZDEMIR ${ }^{1}$
}

*Bu makale, İstanbul Üniversitesi ve Rumeli Balkan Federasyonu işbirliğiyle 2-4 Aralık 2015 tarihlerinde İstanbul'da düzenlenen "I. Dünya Savaşı'nın 100. Yilında Balkanlar ve Göç IV. Uluslararası Kongre" de sunulmuş bildirinin genişletilmesiyle yapılmış araştırma makalesidir.

'Sorumlu yazar/Corresponding author: Nuray Özdemir (Doç. Dr.),

Bolu Abant İzzet Baysal Üniversitesi, Fen Edebiyat Fakültesi Tarih Bölümü Gölköy Kampüsü, Bolu, Türkiye

E-posta: ozdemir_n@ibu.edu.tr

ORCID: 0000-0003-0001-6427

Başvuru/Submitted: 07.02.2019 Revizyon Talebi/Revision Requested: 03.09.2019

Son Revizyon/Last Revision Received:

18.09.2019

Kabul/Accepted: 19.09.2019

Online Yayın/Published Online: 23.10.2019

Atıf/Citation: Ozdemir, Nuray. “I. Dünya Savaşı Yıllarında Balkan Muhacirlerinden Alınan HisseTeavün Vergisi." Türkiyat Mecmuası-Journal of Turkology 29, 2 (2019): 485-498.

https://doi.org/10.26650/iuturkiyat.636843 öz

Balkanlardan Osmanlı topraklarına yerleşen muhacirlere yeni bir hayat kurabilmeleri için askeri ve mali konularda çeşitli muafiyetler tanınmıştır. Muhacirler göç ve iskân tarihinden itibaren altı yıl askerlikten, iki yıl da aşar, temettü, ağnam gibi vergilerden muaf tutulmuşlardır. Ancak I. Dünya Savaşı́nın yol açtığı ekonomik güçlükler uygulamada bir takım sorunları da beraberinde getirmiştir. Örneğin aşar vergisinden muaf tutulan muhacirlerden bazıları yerleşik halkın ürününü de kendi mahsulü gibi göstererek haksız kazanç elde etmişlerdir. Bunun üzerine Hükümet, iskân edilmiş ve zirai üretim yapan muhacirlerin mahsullerinden aşar oranında "Hisse-i Teavün" (Yardım Hissesi) adıyla 17 Haziran 1915'te yeni bir vergi alma yoluna gitmiştir. Böylece hem aşar vergisinin toplanmasında yaşanan suiistimallerin ortadan kaldırılması hem de durumu iyi olan muhacirlerden alınacak vergi ile yine zor durumda olanlara yardım edilmesi amaçlanmıştır. Uygulamada da toplanan verginin muhacirlerin ihtiyaçları için kullanılmasına büyük özen gösterilmiştir. Verginin takip ve tahsili yerel yöneticilerin yanı sıra İskan-ı Muhacirin Komisyonları́nın denetiminde gerçekleşmiştir. Muhacir komisyonlarına ait ambarlarda toplanan buğday, arpa, yulaf gibi tahıllar tohumluk ve yemeklik olarak muhacirlere dağıtılmıştır. Yaklaşık iki yıllık bir uygulamadan sonra Hisse-i Teavün Vergisi kaldırılmıştır. Muhtaç muhacirlere ileride karşılılığı alınmak üzere devletin kendi hazinesinden tohumluk verilmesi uygun görülmüştür.

Bu çalışmada I. Dünya Savaşı'nın yol açtığı ekonomik güçlükler karşısında Hükümet'in daha önce vergiden muaf tuttuğu muhacirlerden aşar oranında aldığı "Hisse-i Teavün" vergisi ve muhacirlerin iaşesi meselesi incelenmiştir. Muhacirlerden yardım payı adı altında alınan verginin yine onların ihtiyaçları için kullanılmasının I. Dünya Savaşı yıllarındaki önemi üzerinde durulmuştur.

Anahtar kelimeler: I. Dünya Savaşı, muhacir, hisse-i teavün, vergi, aşar

\section{ABSTRACT}

The immigrants who moved to Ottoman land from the Balkans were provided with various exemptions in military and financial aspects so that they could start new lives. The immigrants were exempted from military duty for six years from the date of immigration and inhabitation and from various taxes such as 
tithe, dividend and cattle tax for two years. However, the economic difficulties caused by World War I generated some problems in practice. For instance, some of the immigrants who were exempted from tithe tax registered the products of the local public as their own crop and received unfair profits. Then, on 17 June 1915, the Government resorted to collecting a new tax called "Hisse-i Teavün" tax (mutual aid share) from the tithe ratios of the crops from immigrant settlers who did agricultural production. In this way, misconducts experienced in collecting tithe tax would be eliminated and the tax collected from the well-off immigrants would be used to help the needy. Extreme attention was paid to utilize the collected tax for the needs of the immigrants. Follow up and collection of the tax was implemented under the supervision of İskan- Muhacirin (Immigration Settlement) Commissions in addition to local administrators. Gains such as wheat, barley and oat that were collected in the warehouses that belonged to the commissions were distributed to the immigrants for food and seed. After about a two-year practice, this tax was abolished. It was found more appropriate to provide the poor immigrants with the seed from government treasury to be paid later.

This study examined the subsistence of the immigrants and "Hisse-i Teavün" collected based on the ratio of tithe from the immigrants who were previously exempted from tax by the Government as a result of the economic difficulties caused by World War I. In the light of the Prime Ministry Ottoman Archive documents, the study focused on the importance of using the tax collected as mutual aid share to be utilized for the needs of the immigrants during World War I period.

Keywords: World War I, immigrant, hisse-i teavün, tax, tithe

\section{EXTENDED ABSTRACT}

World War I broke out while the Ottoman Empire was busy with settling and catering for hundreds of thousands of immigrants arriving during and after the Balkan Wars. The Ottoman Empire granted various exemptions in military and financial areas for the immigrants to settle into a new life and adapt to it. The immigrants were exempted from military duty for six years from the date of immigration and inhabitation and from various taxes such as tithe, dividend and cattle tax for two years. While struggling to increase its military service and financing, the Ottoman Empire's military and financial exemptions granted to the immigrants have been regarded as a crucial sacrifice.

However, the economic difficulties caused by World War I generated some problems in practice. The exemption from tithe tax granted to immigrants was seen as an opportunity by those peasants not willing to pay taxes. Those peasants tried to avoid taxes by pretending that their products belonged to the immigrants settled in their village. Some of the immigrants caused an unfair profit claiming the villagers' products as their own. As the Ottoman economy was based on agriculture, tithe tax was the most important source for budget revenue. The collection of tithe tax, from various agricultural products by a tenth part, was crucial especially during the years of war. The Ottoman Government was already having numerous difficulties in collecting the taxes in a war environment. It had to make some regulations on exemptions of tithe tax in the face of the abuse caused by immigrants.

Then, on 17 June 1915, the Government resorted to collecting a new tax called "Hisse-i Teavün" tax (mutual aid share) from the tithe ratios of the crops from immigrant settlers who did agricultural production. The "Hisse-i Teavün" was not mentioned as a tax in the regulation that was based on Tithe Tax Regulations. Instead the "Hisse-i Teavün" was regulated as 
benefit share that was seemingly taken at the same ratio as tithe tax over the agricultural products of immigrants exempt from the tax. As the seed taken from immigrants would be turned back to them it was not named a tax. However "Hisse-i Teavün" was the same in practice with tithe tax and thus it was a kind of tax even though not officially stated as so. The purpose of taking "Hisse-i Teavün" was both to eliminate the abuse in collecting tithe tax and to help those in need with the share taken from those immigrants doing well. This practice was then an attempt to find a new reserve for the Ottoman Government struggling with financial difficulties as a result of the World War I. When there was a huge migration to the Ottoman Empire after the Balkan Wars, the aim was to supply the basic needs of the migrants with no burden to the Government during the years of war. The wish was that the collected benefit share would be handed out as seed and feed and used for the immigrants' needs, thus easing the burden on the empire. And in practice special attention was paid to utilize the collected tax for the immigrants' needs.

The follow up and collection of the tax was implemented under the supervision of the Immigration Settlement Commissions in addition to local administrators. Grains like wheat, barley, and oat that were accumulated in warehouses of the Immigrants Commission and were distributed to the immigrants as seeds and edibles. The Ottoman Empire paid attention to continuing aids and exemptions for immigrants during the years of war, too. As "Hisse-i Teavün" was not seen as a tax, the public were often informed that the financial exemptions granted to immigrants was still in effect. Nevertheless trying to accommodate themselves with the new lands in the years of war, the immigrants had difficulty in giving their requested share over their yields to the empire. They even hardly made ends meet. The period of exemption from military service was reduced back to three months and due to war the productive male population was on military service thus creating a decline in production and as a result there was a problem in collecting "Hisse-i Teavün". After almost two years of practice "Hisse-i Teavün" was ended on May $30^{\text {th }} 1917$. Immigrants in need were approved to be given seed from the treasury of the empire for future recompense.

This study examined the subsistence of the immigrants within the Ottoman Empire and "Hisse-i Teavün" collected based on the ratio of tithe from the immigrants who were previously exempt from tax by the Government as a result of the economic difficulties caused by World War I. In light of the Prime Ministry Ottoman Archive documents, the study focused on the importance of using the tax collected as mutual aid share to be utilized for the needs of the immigrants during the period of World War I. 


\section{Giriş}

I. Dünya Savaşı yıllarında Osmanlı Devleti'ni en çok uğraştıran sorunlardan biri Balkan Savaşları sırasında ve sonrasında yaşanan göçler sonucunda gelen muhacirlerin iskânı, iaşesi ve istihdamı olmuştur. Osmanlı Devleti göçmenlere çeşitli yardımlar yaparak sevk ve iskânlarında kolaylıklar sağlamaya çalışmıştır. Kafileler halinde büyük güçlükler sonucu ulaştıkları Osmanlı topraklarında sevk mahallerine ulaşıncaya kadar göçmenlere; can güvenliklerinin sağlanması, bulaşıcı hastalıklara karşı korunmaları, uygun hava şartlarının gözetilmesi, yiyecek ve içecek ihtiyaçlarının giderilmesi, demiryolu ve benzeri nakliye araçlarının ücretsiz ya da düşük ücretlerle tahsis edilmesi gibi destek sağlanmıştır. Göçmenlerin iskân ve iaşesi için vilayetlerde muhacirin komisyonları kurulmuş, devlet geldikleri yerlerin iklimine uygun Osmanlı vilayetlerine uğraştıkları ziraat ve sanat dalına göre yerleştirmeye çalışmıştır. Onlara arazi, zirai malzeme, çift hayvanı ve tohumluk vererek refahlarını sağlamaya önem vermiştir. ${ }^{1}$

Çeşitli yardımların yanında Osmanlı yönetimi muhacirlere iskân edildiği yeni ortama uyum sağlaması ve kısa sürede üretici konuma geçmelerini sağlamak amacıyla vatandaşlık yükümlülüklerinden de belirli bir süre muafiyet tanımıştır. İlk olarak 1856 yılında başlayan göçlerle gelen muhacirlere on sene vergi ve yirmi beş sene askerlik muafiyeti tanınırken 1864 yılından itibaren göçlerin yoğunlaşması üzerine bu sürelerde zamanla azalma olmuştur. ${ }^{2}$

Muhacirlerin muaf tutuldukları vergilerin başında 16-60 yaş tüm erkeklerden alınan yol vergisi (tarik mükellefiyeti) gelmiştir. Tüccar ve zanaatkârlardan alınan temettuat vergisi ile koyun ve keçilerden alınan ağnam vergisini de ödememişlerdir. Dönemin en temel geçim kaynağı tarım olduğundan aşar vergisinden muafiyet muhacirlere büyük kolaylık sağlamıştır. Başlangıçta geliş tarihlerinden itibaren üç sene vergiden muaf tutulmuşlardır. Böylece çiftçi muhacirler kendilerini toparlayıp üretici olacaklarından hazinenin, göçmen masraflarından kurtulacağı ve muafiyet sonrasında devletin aşar gelirlerinin artırılması amaçlanmıştır. Osmanlı Devleti, Bulgaristan ve Şarki Rumeli'den artan göçlerin önüne geçmek ve göçü zorlaştırmak için 1881'den sonra geleceklerin muafiyet müddetini düşürerek bir sene aşardan muaf tutulmalarını uygun görmüştür. Göçü zorlaştırarak Rumeli’de Müslümanların varlığının sürmesinin temini amaçlanmıştır. ${ }^{3}$

Balkan Savaşları sırasında ve sonrasında gelen muhacir sayısının büyük miktarlara ulaşması üzerine sevk, iskân ve iaşe meselelerini yeniden düzenleyen 13 Mayıs 1913 tarihli İskan-1 Muhacirin Nizamnamesi yayınlanmıştır. Askeri ve mali muafiyetleri iki yıl olarak sürdüren Nizamname'nin 28 maddesi şu şekildedir: "Muhacirinin tarih-i hicretlerinden

1 Ahmet Halaçoğlu, Balkan Harbi Sırasında Rumeli'den Türk Göçleri (1912-1913) (Ankara: TTK Yayınları, 1995), 121-122; Fuat Dündar, Ittihat ve Terakki’nin Müslümanları İskân Politikası (1913-1918) (İstanbul: İletişim Yayınları, 2002), 178.

2 Nedim İpek, Imparatorluktan Ulus Devlete Göçler (Trabzon: Serander Yayınları, 2006), 71.

3 Yıldırım Ağanoğlu, Osmanlı'dan Cumhuriyet'e Balkanların Makus Talihi Göç (İstanbul: Kum Saati Yayınları, 2011), 265; İpek, Rumeli'den Anadolu'ya Türk Göçleri (Ankara: TTK Yayınları, 1999), 220-221. 
itibaren altı sene tekalif-i askeriyeden muaf olmalart hakkındaki 20 Şubat 1303 ve iskan edildikleri günden itibaren iki sene tekalif-i maliyeden muaf tutulmalarl hakkındaki 26 Kanunuevvel 1301 tarihli irada-ı seniyye ahkamı bakidir." ${ }^{4}$

Muhacirlerin iskân edildikleri tarihten itibaren iki sene muaf olmalarının 1886 tarihli İrade-i Seniyye hükümlerine dayandırılarak daha önceki savaşlar sonrasında ülkeye gelen muhacirlerin ekonomik açıdan kendilerine yetme tecrübesinden yararlanılarak mali mükellefiyetin devamı öngörülmüştür. Ayrıca mali muafiyetin "hükümetten muavenet-i iskâniye talep ve istihsal etmemiş olan gerek alelade ve gerek mülteci muhacirine şamil bulunduğu" da Şura-yı Devlet'in kararı ile 11 Ağustos 1914 tarihli bir tamim ile bütün vilayet ve müesseselere tebliğ edilmiştir. Bu kararda muhacirler arasında zengin-fakir ayrımı yapılmamıştır. ${ }^{5}$

1914 'te getirilen yeni hükümler uyarınca, çiftlik arazisine yerleştirilen muhacirlerin ev ve hayvan yetiştirmek için gerekli binaları inşa etmek için ve ayrıca kışın evlerini ısıtmak için devlet ormanlarındaki ağaçları kesmelerine izin verilmiştir. Ancak bu hüküm toprakların nadasa bırakıldığı kış aylarında ağaçların topluca kesilmesinde bahane olarak kullanılmıştır. Ormancılık yeni bir kazanç alanı olmuştur. Ayrıca tüm muhacirler belediyelerin resmi belgelerine damga pulu yapıştırma koşulundan da muaf tutulmuştur. Meclis-i Vükela, 4 Mart 1914’te Osmanlı İmparatorluğu'na yerleşmek ve Osmanlı yurttaşı olmak için giren muhacirlere herhangi bir gümrük vergisi ödemeksizin yanlarında bütün ev eşyalarını getirme izni veren geçici bir kararname onaylamıştır. Aynı gün çıkan bir başka kararname, Rumeli'den gelen muhacir tüccarların Osmanlı topraklarına yine tek seferliğine gümrük vergisinden muaf tutulan ticari mallarıyla girmesine izin verilmiştir. $\mathrm{Bu}$ kararnameler başlangıçta yayımlandığında, sadece takip eden üç ay ile sınırlandırılmıştır. Ancak Osmanlı Meclisi tarafından bu uygulamaların süresi I. Dünya Savaşı yıllarında defalarca uzatılmıştır. ${ }^{6}$

\section{I. Dünya Savaşı Yıllarında Muhacirlere Tanınan Muafiyetler}

I. Dünya Savaşı, Osmanlı Devleti'nin Balkan Savaşları sırasında ve sonrasında yaşanan göçlerle gelen yüz binlerce muhacirin iskân ve iaşesiyle meşgul olduğu bir dönemde çıkmıştır. Osmanlı Devleti'nin seferberlik ilanı ve I. Dünya Savaşı'na girişi sürecinde de muhacirler, göç tarihlerinden itibaren altı sene askerlikten ve iskân edildikleri günden itibaren de iki sene mali vergilerden muaf tutulmaya devam edilmişlerdir. Savaşın yol açtığı ekonomik güçlükler karşısında zor durumda olan Osmanlı Devleti için bu muafiyetler büyük bir özveri olarak görülmüştür. Zaman zaman muafiyetlerin sona ereceği yönünde de söylentiler çıkmıştır. Bunun üzerine her ne suretle olursa olsun muhacirlerin askerlik ve vergiden muafiyetinin

4 “İskan-1 Muhacirin Nizamnamesi, 30 Nisan 1329”, Sicilli Kavanini (324-336), Cihan Kütüphanesi Yayın1, 377; Halaçoğlu, Balkan Harbi Sırasında Rumeli’den Türk Göçleri (1912-1913), 113.

5 Ağanoğlu, Osmanlı'dan Cumhuriyet'e Balkanların Makus Talihi Göç, 265-266.

6 Stanford J. Shaw, Birinci Dünya Savaşı’nda Osmanlı Imparatorluğu Savaşa Giriş, çev. Beyza Sümer Aydaş (Ankara: Türk Tarih Kurumu Yayınları, 2014), 502-503. 
devamını esas alan genelgeler basın yoluyla kamuoyuna duyurulmuştur. Bu durum gerekli daire ve memurlara da bildirilmiştir. ${ }^{7}$

I. Dünya Savaşı’nın yol açtığı güçlükler muhacirlere tanınan askeri ve mali muafiyetlerde de zamanla düzenlemeye gidilmesine yol açmıştır. Savaşta Osmanlı Ordusu'nun cephelerde artan asker ihtiyacı muhacirlerin de askere alınmasını gündeme getirmiştir. Bu konuda 15 Nisan 1915'te çıkartılan Mükellefiyet-i Askeriye Kanuna ek bir kanunla savaş durumu nedeniyle Harbiye Nezareti o zamana kadar gelmiş ya da gelmekte olan bütün muhacirleri ihtiyaç görüldüğünde Osmanlı topraklarına giriş tarihlerinden itibaren, yaşlarına göre üç ay içinde silah altına alabilecektir. Altı yıl olan askerlikten muafiyet süresi "seferberliğe mahsus olmak üzere" üç aya düşürülmüştür. ${ }^{8}$

Bazı muhacirler askere gitmemenin yolunu bulup askerlikten kaçmak istemişler ve üç aylık muafiyetle ilgili suiistimaller yaşanmıştır. Aileleri ile beraber iskân edilmelerine rağmen bir süre sonra göç kafilelerinin arasına katılarak başka bölgelere gidip kendilerini yeni gelmiş muhacir gibi göstermişlerdir. Bu gibi suiistimaller hem askerden kaçanların sayısını artırmış hem de kaçanlar, masraf ve iskânları hükümetten karşılandığ 1 halde terk edip gittikleri yerlerde ikinci bir muhacir muamelesine tabi tutulduklarından ek masraflara sebep olmuşlardır. Hükümet tespit edilen bu kişilerin ikinci bir muhacir muamelesine tabi tutulmamadan ahz-1 asker şubelerine teslim edilmesinin üzerinde 1srarla durmuştur. Hükümetin bu kararlılığı karşısında bazı muhacir ailelerinin erkeklerini askere göndermemek için tenha ve bataklık yerlerde barınmayı tercih etmişlerdir. Bunun üzerine 1 Mart 1916 tarihli kanun ile askerlik çağında olan bekâr erkeklerin derhal askere alınmaları benimsenmiştir. Her ne kadar asker kaçaklarının silah altına alınması konusunda kararlı davranılsa da savaş koşulları ve yoğun nüfus hareketleri sebebiyle bu kanun tam olarak uygulanamamıştır. ${ }^{9}$

Savaş yıllarının ekonomik güçlükleri muhacirlere yapılan yardımlar ve tanınan mali muafiyetlerde de bir takım suiistimallerin yaşanmasına yol açmıştır. Osmanlı Hükümeti bunların önüne geçmek için çeşitli tedbirler almak zorunda kalırken muhacirlere yapılan yardımların sürdürülmesine ve zor durumda kalmamalarına özen göstermiştir. Hükümet tarafından iskânları için hayli masraf yapılan muhacirlerden bazıları verilen çift hayvanlarını, zirai alet ve edevatı satarak iskân mahallerini terk etmişler ve her gittikleri yerde kendilerini yeni gelmiş muhacir gibi göstererek ikinci bir iskân muamelesine tabi olmak istemişlerdir. Hükümetin büyük fedakârlıklarla sağladığı yardımları kötüye kullananlar, muhacirlere tanınan bütün muafiyetler ve yardımlardan mahrum bırakılmışlardır. Ayrıca yapılan masraflar da geri istenmiştir. Muhacirlerin izin almaksızın iskân yerlerini terk etmemeleri sağlanmaya çalışılmıştır. ${ }^{10}$

7 “Muhacirine Vergi Muafiyeti”, Tanin, 20 Şubat 1915, 4.

8 Fuat Dündar, İttihat ve Terakki'nin Müslümanlart İskân Politikası (1913-1918), 199; "Muhacirlerin Askerliği", Tasvir-i Efkar, 8 Nisan 1915, 2.

9 Dündar, İttihat ve Terakki'nin Müslümanları İskân Politikast (1913-1918), 200.

10 "Muhacirler Hakkında", Tasvir-i Efkâr, 29 Mart 1915, 3. 
I. Dünya Savaşı ortamında asker sayısını artırma ve finansman bulma meseleleriyle karşı karşıya olan Hükümet için muhacirlere tanınan askeri ve mali muafiyetler büyük bir fedakârlık olmuştur. Bu nedenle muafiyet sürelerine riayet edilmesi ve bunun uzamamasına önem verilmiştir. Muhacirlerin son iskân mahallerindeki sicil nüfuslarına kayıtlarının vakit kaybetmeksizin yaptırılması istenmiştir. Böylece göç ve tescilleri arasında zaman geçmesine imkân vermemeye çalışılmıştır. Çünkü askerlik ile emlak, arazi, yol vergileri gibi kolaylıklar belirli zaman aralıklarıyla sınırlı olduğundan bu sürelerin uzaması istenmemiştir. ${ }^{11}$

\section{Muhacirin Hisse-i Teavünü}

I. Dünya Savaşı'nın yol açtığı ekonomik güçlükler Muhacirin Nizamnamesi'ne göre muhacirlere tanınan iki sene vergi yükümlülüğünden muafiyet konusunda uygulamada bir takım sorunları da beraberinde getirmiştir. Muhacirlere tanınan mali muafiyetler arasında iskan ve iaşeleri hususunda verecekleri dilekçelerden damga vergisi ve Hicaz Demiryolu İane İlmühaberi alınmaması ile temettü (gelir vergisi), emlak, arazi, tarik bedeli (yol vergisi), gümrük, aşar vb. vergiler olmuştur. ${ }^{12}$ Bazı muhacirlerin vergi muafiyetiyle ilgili yaptığı suiistimaller en çok Osmanlı hazinesinin en önemli gelir kaynaklarından biri olan aşar vergisinin tahsilinde görülmüştür. Aşar vergisinden muaf tutulan muhacirler vergi vermek istemeyen köylüler için iyi bir fırsat olarak görülmüştür. Muhacirler iskân edildikleri bölgelerdeki yerli halka ait ürünleri de kendi ürünleri gibi göstererek ihtikâra yol açmışlardır. ${ }^{13}$

Osmanlı Devleti'nde ekonomik faaliyetlerin temelinde tarım olduğundan bütçe gelirlerinin en önemli kaynağını oluşturan çeşitli tarım ürünlerinden alınan aşar (öşr-öşür) vergisinin tahsili özellikle savaş yıllarında büyük önem taşımıştır. Aşar, arazide yetişen mahsullerden onda bir oranında alınan vergi olup dönemlere ve ürün türlerine göre farklı oranlarda tahsil edilmiştir. İhale usulü ile mültezimler tarafından nakdi veya ayni olarak toplanmıştır. Buğday, arpa, mısır, pamuk, haşhaş, zeytin gibi meyve ve sebzeler, ot, tütün, harir (ipek) ve kereste gibi ürünler öşre tabi tutulmuştur. Osmanlı bütçelerinin gelir kalemleri içerisinde her zaman aşar vergisi en önemli yeri teşkil ettiğinden devlet tarımı vergilendirmede her dönemde titiz davranmıştır. ${ }^{14}$

Savaşın hemen öncesinde aşar vergisinin doğrudan toplanmasında mültezimlerin yerini maaşlı devlet memurlarının veya yerel Osmanlı ve Ziraat Bankası çalışanlarının alması ve bu vergi yükümlülüklerini geçmişte ödenenler yerine daha çok mevcut üretime dayandırmak

11 Sezer Arslan, Balkan Savaşları Sonrası Rumeli'den Türk Göçleri ve Osmanlı Devleti'nde İskânları (Yayımlanmamış Yüksek Lisans Tezi, Trakya Üniversitesi, 2008), 124.

12 Mehmet Kaya, "Balkan Savaşları Sırasında Anadolu’ya Göçler ve Karşılaşılan Sorunlar”, History Studies, 5/6, Special Issue on Balkan Wars, November 2013, 4; Arslan, Balkan Savaşları Sonrası Rumeli'den Türk Göçleri ve Osmanlı Devleti'nde İskânlarl, 116.

13 Erdal Taşbaş, Osmanlı Topraklarına Yapılan Göçler ve Muhacirin-i İslamiye Komisyonu (Yayımlanmamış Doktora Tezi, Akdeniz Üniversitesi 2011), 237.

14 Muharrem Öztel, II. Meşrutiyet Dönemi Osmanlı Maliyesi (Yayımlanmamış Doktora Tezi, Marmara Üniversitesi, 2007), 111-112; Vedat Eldem, Harp ve Mütareke Ylllarında Osmanlı İmparatorluğu'nun Ekonomisi, (Ankara: Türk Tarih Kurumu Yayınları, 1994), 88-89. 
için programlar başlatılmıştır. Vergi toplamayı daha verimli hale getirmek için yeni kadastro kayıtları ve nüfus sayımı raporları hazırlamak üzere, Edirne'den başlayarak kısa sürede İmparatorluğun her yerine komiteler gönderilmiştir. Savaş yıllarında yeni vergiler getirilip mevcut vergilere zam yapılırken aşar vergisinin önemi daha da artmıştır. ${ }^{15}$

Seferberlik ve savaş hali dolayısıyla aşar vergisinin tahsilinde zaten sayısız zorluklar yaşayan Osmanlı Hükümeti muhacirlerin yol açtığ 1 suiistimaller karşısında Muhacirin Nizamnamesi'nin yirmi sekizinci maddesinin tanıdığı aşar vergisi ile ilgili muafiyette bir takım düzenlemeler yapmak zorunda kalmıştır. Kırsal kesimde bazı köylüler ürünlerini köylerinde iskân edilmiş muhacirlerinmiş gibi gösterip vergi ödemek istememişlerdir. ${ }^{16}$ Muhacirlerin menfaat gözeterek yerleşik halka ait mahsulatı da kendisininmiş gibi gösterip ihtikâra sapmaları üzerine verginin tahsilinde yaşanan yolsuzluklara son verilmek istenmiştir. Ayrıca Osmanlı ülkesine gelmekte olan göçmen sayısının çokluğu ve mevcut tahsisat ile iskân ve iaşelerinin savaş ortamında sağlanamayacağı görüldüğünden özellikle tohumluk ve yemeklik gibi temel ihtiyaçlarının Hükümete yük olmaksızın temin edilebilmesi için Dâhiliye Nezareti'nce bir düzenlemeye gidilmesi benimsenmiştir. Dâhiliye Nazırı Talat Paşa'nın imzasıyla Sadarete gönderilen 27 Nisan 1331 (10 Mayıs 1915) tarihli ve 199 numaralı tezkirede muhacirlerin aşar vergisinden muaf olan toprak mahsulleri üzerinden "muhacirin hisse-i teavünü” adı altında aşar nispetinde yardım payı şeklinde bir çeşit vergi alınmasının uygun görüldüğü bildirilmiştir. Konunun Meclis-i Vükela'da görüşülerek Hisse-i Teavün'ün tarh ve tahsil usulünü gösteren bir talimatnamenin hazırlanması istenmiştir. ${ }^{17}$

Dâhiliye Nezareti'nin tezkeresi 15 Mayıs 1915 tarihli Meclis-i Vükela toplantısında görüşülerek aşar vergisi oranında "Muhacirin Hisse-i Teavünü“ adıyla ürün üzerinden aynen zahire olarak toplanması ve ambarlarda saklanarak yine muhacirlere dağıtılması öngörülmüştür. ${ }^{18}$ Böylece hem aşar vergisinin toplanmasında yaşanan suiistimallerin ortadan kaldırılması hem de durumu iyi olan muhacirlerden alınacak vergi ile yine zor durumda olanlarına yardım edilmesi amaçlanmıştır. Hisse-i teavünün tarh ve tahsil usulü ile toplanan zahirenin iyi bir şekilde saklanması ve muhacirlere dağıtım hususlarını kaideye bağlayan bir yönetmelik hazırlanması benimsenmiştir. ${ }^{19}$

Dahiliye Nezareti'ne bağlı İskan-1 Aşair ve Muhacirin Müdüriyeti tarafından "Muhacirin Mahsulat- Ziraiyyesinden "Hisse-i Teavün" namıyla resm-i aşar nispetinde alınacak ianenin suret-i derc ve sarfi hakkında talimatname" adılla on bir maddelik bir yönetmelik hazırlanmıştır. 17 Haziran 1915 tarihinden itibaren uygulamaya konulan yönetmelik şu şekildedir: ${ }^{20}$

15 Shaw, Birinci Dünya Savaşı’nda Osmanlı İmparatorluğu Savaşa Giriş, 278.

16 Dündar, İttihat ve Terakki'nin Müslümanları İskân Politikası (1913-1918), 196.

17 Başbakanlık Osmanlı Arşivi (BOA), Bab-ı Ali Evrak Odası (BEO),4355/326585, s.3.(03.B.1333/17 Mayıs 1915)

18 BOA, Meclis-i Vükela Mazbataları (MV), 198/3.(01.B.1333/15 Mayıs 1915)

19 BOA, BEO, 4355/326585, s.3.(03.B.1333/17 Mayıs 1915)

20 BOA, Dahiliye Nezareti Hukuk Müşavirliği (DH.HMŞ), 27/62.(04.Ş.1333/17 Haziran 1915) 
Birinci Madde: Tekalif-i öşriyyeden muaf olan muhacirin mahsulat-1 arziyyesinden (toprak mahsullerinden) resm-i aşardan müstesna bulunduğu müddetçe aşar nispetinde ve aşarın tabi olduğu usul-i cibayet daireside "hisse-i teavün" namıla suret-i derc ve sarfi mevat-1 atiyyede münderiç iane-i mahsusa istifa olunur.

İkinci Madde: Her kasabada mevcut ve tekalif-i öşriyyeden müstesna olan muhacirin mahsulat-1 arziyyesi mükellefin-i saire mahsulatının tabi tutulacağı usul ve şerait dairesinde sebt (yazma,) ve kayd edilir. Şu kadar ki "hisse-i teavün" ün mükellefin-i saireden alınan resimden tefriki için defter-i mahsusasında ayrı ayrı haneler açtırılır.

Üçüncü Madde: Muhacirine aid ve hisse-i teavüne tabi mahsulatın sebt ve kaydı ve mukabilinin (karşılık) derç ve tahsili masrafı mükellefin-i saireye aid mahsulat resm-i aşarı ile ihale ve nakden veya aynen cibayet veya emaneten idare hallerinde bu resmin tabi olduğu masraf nisbetindedir. Yani muhacirine aid mahsulat hisse-i teavünün mükellefin-i saireye aid mahsulat resmi aşarıyla birlikte aynen veya nakden ihalesi halinde muhacirinden tahsil olunacak bedel-i ihale tamamen "hisse-i teavün" olub aşarın emanet suretiyle idaresi halinde de hisse-i teavüne isabet eden masraf "masraf-1 cibaiyye" namıla cihet-i maliyece hasılattan tenzil olunur. İcabı taktirinde ayrıca memurin-i mahsusa dahi tayin edilebilir.

Dördüncü Madde: Aşar nizamnamesi ile teamül-i mahalliye nazaran aynen alınması icap edip de durmakla bozulmayan mahsulattan alınacak hisse-i teavün doğrudan doğruya hazineye aid resm-i aşar gibi cibayet ve ba-mazbata muhacirin komisyonlarına devrolunur. Beşinci Madde: Resm-i aşarı bedelen tahsil edilen mahsulatın "hisse-i teavün"ü aynıyla hazine-i maliyeye aid bedelat-1 misüllü (benzer gibi) ve fakat muhacirin komisyonları hesabına olarak istifa olunur.

Altıncı Madde: Resm-i aşarı mükellefin-i saireden aynen alınabilen mahsulattan hisse-i teavün olarak muhacirinden alınanları aşar anbarlarına derc ve iddihar (toplamak) olunmak caiz olduğu gibi bunlar için muhacirin komisyonlarınca sureti mahsusada anbar tedarik edilerek gerek bidayeten (başlangıçta) ve gerek aşar anbarlarından naklen orada muhafazaları temin edilebilir. Her halde aşar memurini muhacirin hisse-i tevününün dahi hüsn-i suretle kayd ve zabtından mesul ve bununla alakadardır. Resmi aşarı mükellefin-i saireden nakden alına gelen mahsulat için hisse-i teavün olarak muhacirinden alınacak bedelat dahi vilayet iskan muhacirin komisyonu namına olmak şartıyla emanet hesabına kayd ettirilir. Hisse-i teavünün cibayet ve idare masrafı resm-i aşarın cibayet ve idare masrafı nispetine göre hazine-i maliyeye aynen veya nakden terk olunur. Ve bu hisse mal sandıklarınca irad-1 kayd edilir. Bununla beraber hisse-i teavünün ayniyat kısmını muhafaza için anbar eminleri tayinine lüzum-1 mübrem (kaçınılmaz) görünürse iskan-1 muhacirin komisyonlarının memur-1 mesulü sıfatıyla tayin ve istihdamı mücazdır (uygun görülmüş). Memur tayinini istilzam (gerekme, gerektirecek) edecek bir mikdarı ihtiva etmeyen köy anbarlarının muhafazasından dahi karye heyet-i ihtiyariyyesi mesul olur.

Yedinci Madde: Anbarlarda mevcut zahair (zahireler) ve mahsulatın cins ve mikdarı her ay nihayetinde vilayet veya liva muhacirin komisyonuna bildirilecektir.

Sekizinci Madde: Vilayet veya müstakil liva muhacirin komisyonları mülhakatındaki (merkeze bağl1 yerler) anbarlarda mevcut zahair ve hububatdan buğday, arpa, alaf (ot, saman gibi hayvan yemi) gibi tohumluk ve yemeklik olarak muhacirine aynen tevzii(dağıtma) iktiza (gereken) eden hububat ve zehairden maada findik, ceviz ve badem gibi aynen tevzi edilemeyecek olan mahsulatı vilayet veya müstakil liva muhacirin komisyonlarının münasib göreceği şekl ve surette müzayedeye vaz ve Osmani vilayet iskan muhacirin 


\begin{abstract}
komisyonu hesabına olarak emaneten mal sandiklarına tevdi olunur.
Dokuzuncu Madde: Gerek zahairin aynen tevzii ve gerek hisse-i teavünden nakden cibayet edilen mikdar ile mahsulatn bey (satma) ve füruhtundan (satma) tahsil eden mikdarın yani emaneten mal sanduğunda bulunan mübalağın muhacirin ihtiyacatının teminine medar olacak surette sarfı alet ve edevat-1 ziraiyye mübayaası (satın alma) muhacirin tahsisatının suret-i sarfi hakkındaki kavaid ve usul tahtında icra olunur.

Onuncu Madde: Aynen veya bedelen istifa (alınan ödetilen) olunan mahsulat ve mebaliğ ile bunlardan vuku bulan sarfiyat mikdarı hakkında her üç ayda bir tanzim ve merkez nezarete irsal edilmekte olan sarfiyat cedvellerinde hisse-i teavün hasılat ve sarfiyatı namıla bir fasl-1 mahsus açılarak tafsilat ve izahat verilecektir.

On Birinci Madde: Zahair ve mahsulatın tarz-1 cibayet ve idare ve muamelat-1 kuyudiyye ve hesabiyyelerinin tanzim ve temini ve ayniyat ve bedelatın takib ve tahsili alel-ricat memurin-i mükellefiye ve maliyeye ve iskan-1 muhacirin memurlarına aid ve raci olduğu gibi icab ettiği takdirde işbu talimatname ile tevzih edilen mevad dairesinde izahnameler tanzimi vali veya mutasarrıflara aiddir.
\end{abstract}

Aşar Nizamnamesi esas alınarak hazırlanan yönetmelikte, hisse-i teavünden bir vergi olarak söz edilmemiştir. Hisse-i Teavün, vergiden muaf tutulan muhacirlerin toprak mahsulleri üzerinden aşar vergisi oranında zahire olarak alınan yardım payı olarak sistemleştirilmiştir. Muhacirlerden alınan tohumluk yine onlara verileceğinden bir vergi olarak telakki edilmemiştir. ${ }^{21}$

Hisse-i teavün, aşar vergisinin tabi olduğu tarh, tahsil, ambarlarda saklama vs. gibi aynı usullere tabi tutulmuştur. Hisse-i teavünün diğer mükelleflerden alınan vergiden ayrımı için özel bir defter tutulması ve toplanan zahirenin de muhacirin komisyonları hesabına aktarılması benimsenmiştir. Muhacir komisyonlarına ait ambarlarda toplanan buğday, arpa, yulaf gibi tahıllar tohumluk ve yemeklik olarak yine muhacirlere dağıtılmıştır. Yönetmeliğin onuncu maddesinde ayni ve bedel olarak toplanan yardım payları ile yapılan harcamalar hakkında her üç ayda bir sarfiyat cetvelleri düzenlenip Dâhiliye Nezareti’ne gönderilmesi istenerek sıkı bir denetim kurulmaya çalışılmıştır. ${ }^{22}$

Osmanlı Devleti savaş yıllarında da muhacirlere yaptığı yardımları ve tanıdığı muafiyetleri sürdürmeye özen göstermiştir. Dönemin basınında da hisse-i teavünün hazırlık sürecinde muhacirlere tanınan muafiyetlerin devam ettiği sıklıkla basın yoluyla duyurulmuştur. Hükümetten iskân için yardım talep eden muhacirlerin İskan-ı Muhacirin Nizamnamesinin yirmi sekizinci maddesi gereğince iskan tarihlerinden itibaren iki sene müddetle tekalif-i maliyeden istisna olduklarına dair Şura-yı Devlet kararı ilan edilmiştir. ${ }^{23}$ Hisse-i teavün bir vergi olarak görülmediğinden muhacirlere tanınan mali muafiyetlerin sürdürüldüğü üzerinde durulmuştur.

21 BOA, Dahiliye Nezareti Hukuk Müşavirliği (DH.HMŞ), 27/62.(04.Ş.1333/17 Haziran 1915); BOA, BEO, 4472/335381.(13.Ş.1335/4 Haziran 1917).

22 BOA, DH.HMŞ, 27/62.(04.Ş.1333/17 Haziran 1915)

23 "Mafviyet", Tasvir-i Efkar, 9 Haziran 1915, 2. 
Ancak savaş yıllarında Hükümetin aşar vergisini toplamakta karşılaştığı güçlükler ve vergi gelirlerinde yaşanan düşüş göz önüne alındığında daha yeni yerleştiği topraklara uyum sağlamaya çalışan muhacirlerin de bu vergiyi ödeme düzeylerinin yüksek olmadığ aşikârdır. Muhacirlere tanınan askerlikten muafiyet süresinin üç aya indirilmesi ve üretken erkek nüfusun askere gitmesi de üretimde zaten düşüşe yol açtığından hisse-i teavünün toplanmasında sorunlar yaşanmıştır. Muafiyet süreleri biten ve ancak geçimlerini sağlayabilecek kadar üretim yapabilen muhacirler dahi aşar vergilerini ödemekte büyük zorluklar yaşadığında hisse-i teavünden vazgeçilmiştir.

\section{Hisse-i Teavün'ün Kaldırılışı}

Muhacirin Nizamnamesi'ne göre iskân tarihlerinden itibaren iki y1l süre ile aşar vergisinden muaf tutulan muhacirlerin ürettikleri toprak mahsullerinden aşar oranında hisse-i teavün adıyla Meclis-i Vükela kararı ile zahire alınması Maliye Nezareti’nce kanun dışı bir uygulama olarak değerlendirilmiştir. Sadarete bu konuda Maliye Nezareti’nce gönderilen 12 Mart 1917 tarihli 405/3 numaralı tezkire ile 1915 yılından itibaren alınmakta olan hisse-i teavünün tahsilinin muhacirlerden muaf oldukları bir verginin başka bir isimle alınması olduğu belirtilmiştir. Bunun aslında yeni bir vergi vaz ve tarhından başka bir şey olmadığg, kanunsuz bir vergi tahsiline izin verilmemesi gerektiğinden bu uygulamadan vaz geçilmesi talep edilmiştir. ${ }^{24}$

Maliye Nezareti'nin bu isteğine karşı Dâhiliye Nezareti uygulamanın devamından yana bir tutum izlemiştir. Savaş yıllarında muhacirlere verilen tohumların düzenli bir şekilde tahsil olunarak tekrar kendilerine iade etmek üzere adeta muhacirin idaresi ile muhacirler arasında akdedilmiş bir özel mukaveleye dayanan bir uygulama olduğu savunulmuştur. Savaş yıllarında muhacirlerin ihtiyaçlarının karşılanmasında önemli bir katkı olarak görüldüğünden Dahiliye Nezareti bu uygulamadan vazgeçmek istememiştir. Muhacirlerden alınan tohumluğun yine muhacirlere dağıtılmasının yeni bir vergi olarak kabul edilemeyeceği ve bu uygulamanın devamı savunulmuştur. Dâhiliye Nezareti Aşair ve Muhacirin Müdüriyet-i Umumiyyesi iskân şubesince bu istek 27 Mayıs 1917 tarihli bir tezkire ile Sadaret'e bildirerek Meclis-i Vükela'da bu konunun görüşülmesini ve hisse-i teavünün tahsilinin devamının Maliye Nezareti'ne tebliğini talep etmiştir. ${ }^{25}$

Dahiliye Nezareti'nin bu talebi 30 Mayıs 1917 tarihli Meclis-i Vükela toplantısında görüşülerek muhacirin hisse-i teavünü hakkında şu karar alınmıştır: "Muhacirinden hisse-i teavün namı ile zahire ahzı usulünün bade-zin devam-ı meriyetine sarf-ı nazar olunarak muhtacin muhacirine tavizen tohumluk itası münasip görüldüğ̈̈nden keyfiyetin nezaret-i müşarün-ileyhe tebliği tezkir kllındı." ${ }^{26}$

Muhacirlerden 17 Haziran 1915 tarihinden itibaren yaklaşık iki yıl boyunca hisse-i

$24 B O A, B E O, 4472 / 335381 .(13 . S ̧ .1335 / 4$ Haziran 1917)

$25 B O A, B E O, 4472 / 335381 .(13 . S ̧ .1335 / 4$ Haziran 1917)

26 BOA, $M V$, 208/47.(08.Ş.1335/30 Mayıs 1917) 
teavün adı altında yardım payı şeklinde zahire alınması usulüne son verilmiştir. İhtiyaç sahibi çiftçilere ileride karşılı̆̆ alınmak üzere devlet hazinesinden tohumluk verilmesi uygun görülmüştür. Bundan sonra hisse-i teavün uygulamasından vazgeçilirken o zamana kadar alınmış olanlar hakkında eski talimatname dairesinde muamele yapılması istenmiştir. Bu durum Dâhiliye Nezareti'nce bir tamimle vilayetlere bildirilmiştir. ${ }^{27}$ Gazeteler yoluyla da kamuoyuna duyurulmuştur. ${ }^{28}$

\section{Sonuç}

Yeni bir hayat kurma ve üretken hale geçmelerine kolaylık sağlamak amacıyla vergiden muaf tutulan muhacirlerden 17 Haziran 1915'ten itibaren aşar vergisi oranında "Hisse-i Teavün” adıyla yardım payı alınması I. Dünya Savaşı'nın yol açtığı ekonomik güçlüklerle mücadele eden Osmanlı Hükümeti için yeni bir kaynak bulma girişimi olmuştur. Balkan Savaşları sonrasında Osmanlı ülkesine gelen göçmen sayısının çokluğu düşünüldügüünde savaş yıllarında muhacirlerin temel ihtiyaçlarının Hükümete yük olmaksızın temini hedeflenmiştir. Muhacirlerden aşar vergisi oranında aynen zahire olarak toplanan yardım payının tohumluk ve yemlik olarak dağıtılıp yine muhacirlerin ihtiyaçları için kullanılması ile devletin yükü hafifletilmek istenmiştir.

Muhacirin Nizamnamesi ile iki yıl mali yükümlülükten muaf tutuldukları için Hisse-i Teavün, muhacirlerden alınan bir yardım payı olarak değerlendirilmiştir. Gerek bu konudaki Dâhiliye Nezareti'nin önerilerinde ve Meclis-i Vükela kararında gerekse hazırlanan yönetmelikte Hisse-i Teavün'den yeni bir vergi olarak söz edilmemiştir. Ancak aşar vergisiyle birebir örtüşen bir uygulama olup resmen ifade edilmese de bir çeşit vergidir. Muhacirlerden aşar vergisi oranında alınan zahirenin yine onlara tohumluk olarak dağıtılarak savaş yıllarında muhacirlerin iaşesinin hazineye yeni bir yük getirmeden sağlanması hedeflenmiştir.

Osmanlı Devleti'nin vergi muafiyeti tanıdığ 1 muhacirlerden savaş yıllarında da olsa yardım payı şeklinde bir çeşit vergi toplanması kanunsuz bir uygulama olduğu gerekçesiyle "hisse-i teavün" Osmanlı vergi sistemiyle bağdaştırılamamış ve iki yıllık bir uygulamadan sonra vazgeçilmiştir. Muhacirlere yönelik böyle özel bir uygulamaya gidilmesi I. Dünya Savaşı'nın yarattığı ekonomik güçlüklerle uğraşan Osmanlı Hükümeti’nin, muhacirlerin sorunlarına ilgisiz kalmayarak onların temel ihtiyaçlarının karşılanmasında gösterdiği kararlılık ve bunun için kaynak yaratma çabası dikkate değerdir.

27 BOA, Dahiliye Nezareti Emniyet-i Umumiye Müdüriyeti Evrak Odası (DH.EUM.VRK), 17/76.(4.N.1335/24 Haziran 1917)

28 “Tebligat-1 Umumiye", Takvim-i Vakayi, 27 Haziran 1333, 1; "Muhacirinden Hisse-i Teavün Alınmayacak", Tasvir-i Efkar, 28 Haziran 1917, 1; "Muhacirine Hisse-i Teavün Namıyla Alınan Zahire", Tanin, 27 Haziran $1917,3$. 


\section{Kaynaklar}

"İskan-1 Muhacirin Nizamnamesi, 30 Nisan 1329”, Sicilli Kavanini (324-336), Cihan Kütüphanesi Yayını. (Basım yeri ve yılı belirtilmemiş)

Ağanoğlu, Yıldırım. Osmanlı'dan Cumhuriyet'e Balkanların Makus Talihi Gö̧̧. İstanbul: Kum Saati Yayınları, 2011.

Arslan, Sezer. Balkan Savaşları Sonrası Rumeli'den Türk Göçleri ve Osmanlı Devleti'nde İskânları. Yayımlanmamış Yüksek Lisans Tezi, Trakya Üniversitesi, 2008.

Dündar, Fuat. İttihat ve Terakki'nin Müslümanları İskân Politikası (1913-1918).İstanbul: İletişim Yayınları, 2002.

Eldem, Vedat. Harp ve Mütareke Yıllarında Osmanlı İmparatorluğu'nun Ekonomisi. Ankara: Türk Tarih Kurumu Yayınları, 1994.

Halaçoğlu, Ahmet. Balkan Harbi Sirasında Rumeli'den Türk Göçleri (1912-1913). Ankara: TTK Yayınları, 1995.

İpek, Nedim. İmparatorluktan Ulus Devlete Göçler. Trabzon: Serander Yayınları, 2006.

İpek, Nedim. Rumeli'den Anadolu'ya Türk Göçleri. Ankara: TTK Yayınları, 1999.

Kaya, Mehmet."Balkan Savaşları Sırasında Anadolu'ya Göçler ve Karşılaşılan Sorunlar”, History Studies, 5/6, Special Issue on Balkan Wars, (2013), 1-16.

Öztel, Muharrem. II. Meşrutiyet Dönemi Osmanlı Maliyesi. Yayınlanmamış Doktora Tezi, Marmara Üniversitesi, 2007.

Shaw, Stanford J. Birinci Dünya Savaşı’nda Osmanlı İmparatorluğu Savaşa Giriş. Çeviren Beyza Sümer Aydaş, Ankara: Türk Tarih Kurumu Yayınları, 2014.

Taşbaş, Erdal. Osmanlı Topraklarına Yapılan Göçler ve Muhacirin-i İslamiye Komisyonu. Yayımlanmamış Doktora Tezi, Akdeniz Üniversitesi, 2011.

\section{Arşivler}

Başbakanlık Osmanlı Arşivi

\section{Süreli Yayınlar}

Takvim-i Vakayi

Tanin

Tasvir-i Efkâr 
